\title{
The Impact of Scientific Creative Thinking Skills on Scientific Process Skills
}

\author{
Sibel Demir Kaçan ${ }^{1, *}$, and Fatma Şahin ${ }^{2}$ \\ ${ }^{1}$ Ondokuz Mayıs University Sciences, Education Faculty Science Education Department, Türkiye \\ ${ }^{2}$ Marmara University Sciences, Education Faculty Science Education Department, Türkiye
}

\begin{abstract}
The research aims to determine "the Impact of Scientific Creative Thinking Skills on Scientific Process Skills". Thus, the research was performed with 24 teacher candidates in the control group and 24 teacher candidates in the experimental group in the second class of the Department of Science Teaching in a university in Istanbul Province. In the experimental group of the research, the laboratory program to be designed by the researchers on the basis of scientific discussion and research; and in the control group, the conventionally designed laboratory program were applied for an academic semester. The research data was gained through "Scientific Creativity Test" to be developed by Hu and Adey [14] and adapted by Kadayıfçı [16]; "Scientific Process Skills Test" to be developed by Okey, Wise and Burns, and adapted by Geban, Aşkar and Özkan into Turkish. The conclusions to be reached by the research are in favour of the experimental group and the last application, and it has positive impact on the opinions of the teacher candidates related with the development of the scientific creativity skills.
\end{abstract}

Keywords: Science education, scientific creativity skill, scientific process skill

\section{Introduction}

According to the "Global Competitiveness Report 2012" that is annually published by the World Economic Forum, Turkey is ranked as 59th among 142 countries and it is lower than the average [3]. The indicators referring to the innovation and entrepreneurship are defined with the levels of creativity. In order to develop a new and important product for the innovation, the creativity skill is required. The formation of a "new" product means that its use should be "something different" from previous usages. On the other hand, it complies with the "benefit" or "value" feature of the creativity in terms of the innovation. For the innovation, in the theoretical meaning, there at least should be the solution to a problem (like non-existence of a certain product in the market) [31]. All the innovative approaches start with a creative idea [10]. The creativity and the innovation are the effective method of teaching providing a constructivist learning environment that is required for the active

\footnotetext{
*Corresponding author: sibelfe@,hotmail.com; this article is part of the first author's doctoral thesis.
} 
participation and integration of new information with previous learnings for the students to use their cognitive processes and skills [32]. The development of creative and innovative skills are in central importance in the education and these skills ensure a strong relationship between the information and the learning, so the innovative teaching is required for the creative learning [13]. The creativity contains the science and daily life [12]. Since, the problem solving, formation of a hypothesis, test design, technical innovations need certain form of the creativity [15]. According to Kocabas [19], the scientific creativity means the motivation for scientific researches, formulation of the research problems through the information, forming a comprehensive general field for the solution of a scientific problem, the skill of searching complying with the causes and similarities, and detailed search patience with the strength. Park [26] states the scientific creativity on three dimensions which are creative thinking, scientific information and scientific research and inquiry skills. On the other hand, Zhang, Liu and Lin [33] mention the crucial existence of some basic features like internal motivation, autonomy and initiative for the scientific creativity, together with their insufficiency, alone. Alexander (1992) and Amabile (1987) stated that all the creativities have their certain field of impact and components, so it is necessary to distinguish the scientific creativity from general creativity [quoted by 15]. Likewise, Hu and Adey [14] also mentioned that the scientific creativity is a special need other than usual creativity tests, so they developed "the scientific creativity model" unique to the field. The scientific creativity model to be formed by Hu and Adey [14] on the other hand, consists of three dimensions which are the process, characteristic and product. According to Demir [9], "The scientific creative thinking skill: It can be defined as a skill of thinking providing the formation of numerous original ideas in various fields for the solution of a problem for which the solution is required by the individual, with an innovative and interdisciplinary approach including the science, technology and art (aesthetics). With reference to this definition, the scientific creativity is considered as a multi-dimensional and equipped field ensuring either uniqueness to the field or the aesthetic approaches of various disciplines to bring together under the same roof."

When the research based learning is considered for the development of the scientific process skills, the interaction of them will be quite effective on the science education [28]. Likewise, the study of Ünal Çoban [30] indicated that the scientific process skills of the science teaching candidates dramatically changed with the laboratory activities on the basis of research and inquiry which are reinforced with the argumentation. The scientific process skills are necessary for the scientific creativity and creative thinking [23]. Meador [22] emphasizes that thinking and discussing like a scientist are necessary for the scientific process skills and creativity, and the creative thinking and the science process skill are one in another, so the scientific creativity skills of the individuals who use the scientific process skills are better. Aktamış and Ergin [2] define the scientific process skills as the requirement for all people in the society to be a scientific reader and the people having these skills use them to solve the problems in their daily lives. They also state that the creative thinking is again important to notice the problems in the daily lives and the scientific process skills and scientific creativity interact with each other in creative thinking models. Liang [21] states that many researchers focus on the creative thinking, products and processes of the scientists in the researches on the scientific creativity, few researchers focus on the creativity of the students. Therefore, it is considered that the number of the researches on the scientific creativity of the students, teachers and candidate teachers should be increased. With reference to this point, the problem of the research to determine "The Impact of Scientific Creative Thinking Skills on Scientific Process Skills". 


\section{Methodology}

It is research model (pattern) that is the research plan to be developed by the researcher to control the variance in order to test the hypothesis or to answer the research questions [4; 5]. The mixed model is a dominant model that provides the qualitative and quantitative methods to distinguish, define and unite [24]. This mixed model is used for the research. The universe of this research is the 1 st and 2 nd education programs students in the Department of Science Teaching in a university in Istanbul. The working group of the research consists of 2 nd grade of the Department of Science Teaching of the same university. The students selecting this course among candidate teachers in the 1st education program formed the control group and the candidate teachers from the 2nd education program formed the experimental group. Thus, this research was conducted with 24 candidate teachers in the control group and 24 candidate teachers in the experimental group in the Department of Science Teaching. The program to be developed by the researchers was designed with reference to the conventional laboratory program for the control group and $5 \mathrm{E}$ model on the basis of scientific discussion and research for the experimental group.

The scientific process skills test was developed by Okey, Wise and Burns in 1985 with 36 questions with 5 alternative answers for each question; it was translated and adapted by Geban, Aşkar and Özkan in 1992, and the test with 0,85 scale reliability was reached by [29] and [6]. The reliability factor of this test for present research was 0,76 Cronbach alpha and this value is considered as an acceptable value, so the test was applied to the candidate teachers in the control and experiment groups as the pre- and post-application. In the study, the reliability factor of the scientific creativity test to be developed originally by $\mathrm{Hu}$ and Adey [14] with validated 7 open-ended questions was calculated as 0,89 and the reliability factor of the test to be adapted by Kadayıfçı [16] was calculated as 0,73. Besides, the Cronbach alpha value of the scientific creativity test for the present study was defined as 0,74 and the test was applied to the control and experiment groups as the pre- and postapplication. In the analysis of the qualitative data to be extracted from the research, the usual distribution was firstly considered and "the Scientific Process Skills Test" was normal for all four groups. Therefore, the t-test analysis was performed for the measuring tool. In addition to all these analysis, the "quantified" qualitative data coming from the pre- and post-applications was statistically analysed; first of all, it was determined if the groups indicated normal distribution for each measuring tool. Since the data had to be $p>0,05$, the "Quantified" Scientific Creativity Questions were normally distributed for all four groups. Since the "quantified" qualitative data for each group was distributed normally, this data to be gained was applied t-test. In the research, the scientific creativity test consisting of 7 open-ended questions and was developed by Hu and Adey [14] was presented as pre- and post-application in both control and experiment groups. The data to be taken from all the candidate teachers personally was assessed by the researcher with content analysis in terms of the qualifications with reference to the fluency, flexibility and uniqueness features of the scientific creativity. For the assurance of the reliability of the assessment form of the researcher, the assessments of 2 different experts were taken and the compatibility of the researcher with the experts were checked as percentage. As a result of the consideration of the data to be gained, it was found that the compatibility rates change between $81,63 \%$ to $96,55 \%$, the reliability and the validity of the assessment of the researcher was provided. For the test to be applied to indicate the scientific creativity, the assessment criteria to be developed by $\mathrm{Hu}$ and Adey to assess all three dimensions of the scientific creativity in preand post-applications in the control and experiment groups were followed. 


\section{Findings}

Findings from this study are presented in tables and figures (table 3.1.; table 3.2.; table3.3; table3.4; table3.5.; figure3.1; figure3.2) below.

The fluency points to be gained through first six articles of the scientific creativity test from the candidate teachers are given in below table. There is not any data from the 7 th question on apple picking machine having no fluency criteria, so no data from this question.

Table 3.1. Fluency Points of the Candidate Teachers from the Scientific Creativity Test

\begin{tabular}{lllllllllllll}
\hline & Question1 & \multicolumn{2}{c}{ Question2 } & \multicolumn{2}{l}{ Question3 } & \multicolumn{2}{c}{ Question4 } & \multicolumn{2}{l}{ Question5 } & \multicolumn{2}{c}{ Question6 } \\
\hline & Pre & Post & Pre & Post & Pre & Post & Pre & Post & Pre & Post & Pre & Post \\
\hline Control & 146 & 180 & 136 & 161 & 89 & 85 & 99 & 89 & 79 & 78 & 69 & 55 \\
\hline Experiment & 134 & 222 & 124 & 189 & 79 & 111 & 101 & 147 & 78 & 88 & 43 & 68 \\
\hline
\end{tabular}

As it is seen on Table 3.1., the fluency grades of 6 questions on the scientific creativity, there are findings in favour of the experimental group and the post-application.

The flexibility points to be gained through five articles of the scientific creativity test from the candidate teachers are given in below table. There is no flexibility criteria in the question 5, there is no data from this question.

Table 3.2. Flexibility Points of the Candidate Teachers from the Scientific Creativity Test

\begin{tabular}{llllllllllllll}
\hline & \multicolumn{2}{c}{ Question1 } & \multicolumn{2}{l}{ Question2 } & \multicolumn{2}{c}{ Question3 } & \multicolumn{2}{c}{ Question4 } & \multicolumn{2}{c}{ Question5 } & \multicolumn{2}{c}{ Question7 } \\
\hline & Pre & Post & Pre & Post & Pre & Post & Pre & Post & Pre & Post & Pre & Post \\
\hline Control & 62 & 70 & 70 & 57 & 40 & 43 & 47 & 43 & 129 & 117 & 153 & 138 \\
\hline Experiment & 56 & 100 & 60 & 103 & 43 & 71 & 58 & 98 & 99 & 183 & 171 & 237 \\
\hline
\end{tabular}

As it is seen on Table 3.2, the flexibility grades of five questions on the scientific creativity, there are findings in favour of the experimental group and the post-application.

The uniqueness points to be gained through the scientific creativity test from the candidate teachers are given in below table.

Table 3.3. Uniqueness Points of the Candidate Teachers from the Scientific Creativity Test

\begin{tabular}{|c|c|c|c|c|c|c|c|c|c|c|c|c|c|c|}
\hline & \multicolumn{2}{|c|}{ Question1 } & \multicolumn{2}{|c|}{ Question2 } & \multicolumn{2}{|c|}{ Question3 } & \multicolumn{2}{|c|}{ Question4 } & \multicolumn{2}{|c|}{ Question5 } & \multicolumn{2}{|c|}{ Question7 } & \multicolumn{2}{|c|}{ Question1 } \\
\hline Experiment & 103 & 199 & 116 & 205 & 78 & 118 & 111 & 190 & 26 & 31 & 72 & 122 & 75 & 97 \\
\hline
\end{tabular}

As it is seen on Table 3.3, the uniqueness grades of all questions on the scientific creativity, there are findings in favour of the experimental group and the post-application.

Thus, in order to support these "quantified" qualitative data quantitatively, t-test of the scientific creativity test was also performed inside and among the groups.

Table 3.4. Pre- and Post-Application Findings for Control and Experiment Groups

\begin{tabular}{lllll}
\hline & N & Ort. & t & p \\
\hline Experiment pre & 24 & 99,67 & 5,315 & 0,000 \\
\hline Experiment post & 24 & 137,54 & & \\
\hline Control pre & 24 & 99,17 & 0,077 & 0,939 \\
\hline Control post & 24 & 99,50 & & \\
\hline
\end{tabular}


As it is seen on Table 3.4, the t-test results inside the groups are in favour of the experimental group and the post-application, and there is not any difference between the pre- and post-application of the control group.

The below tables present the qualitative findings in relation with the Question 1 "Please write the scientific use of a piece of glass as much as possible. For instance, 'a test tube can be made" for control and experiment groups.

Table 3.5. Categories to be Generated with reference to the "Piece of Glass Question" in the Scientific Creativity Test of Candidate Teachers

\begin{tabular}{cl}
\hline Category no & Category name \\
\hline E1 & Use for storing \\
\hline E2 & Use for making tests \\
\hline E3 & Use for innovation \\
\hline E4 & General use \\
\hline E5 & Use for physics \\
\hline E6 & Use for chemistry \\
\hline E7 & Use for biology \\
\hline E8 & Use for health / medicine \\
\hline E9 & Interdisciplinary use \\
\hline E10 & Use as a device \\
\hline E11 & Use for research \\
\hline E12 & Other \\
\hline
\end{tabular}

The answers of the candidate teachers were categorized here. As it is seen on the Table 3.5 , there are 12 categories for this question in total. One of the categories is the "other" and the answers which are not considered in other categories with similar characteristics are taken into this category. These categories were defined for each answer to be given and the category of related answer was indicated next to the answers in the part of the annexes.

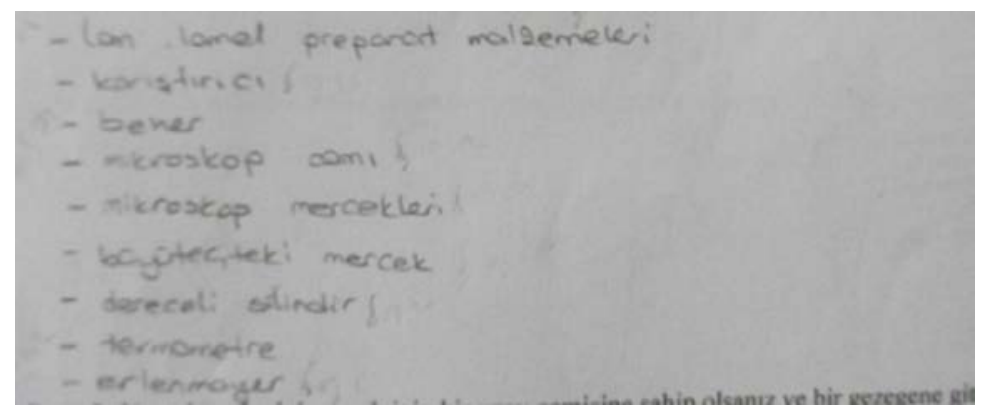

Figure 3. 1. Sample of Candidate Teacher having the code of dö14

For the $7^{\text {th }}$ question the scientific creativity test, the categories to be formed by $\mathrm{Hu}$ and Adey [14] were used. There are 7 categories for this question in total. These categories were determined for each given drawing. For each function to be drawn in relation with the apple picking machine in the scientific creativity test, 3 point is given. There are 3 examples from pre- and post-applications of the candidate students either in control group or in experiment group. 


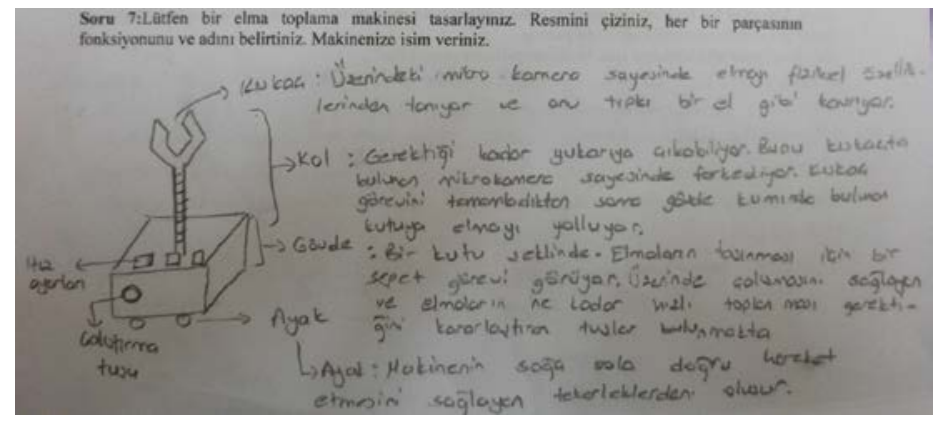

Figure 3.2. Drawing of Candidate Teacher having the Code of "dö24"

The candidate teacher having the code of dö 24 performed the functions of reaching to the apple, finding the apple, picking the apple and placing into the carrying vehicle in this figure.

\section{Discussion and conclusion}

The conclusions to be reached by the research are in favour of the experimental group and the last application, and it has positive impact on the opinions of the teacher candidates related with the development of the scientific creativity skills. According to Kaptan and Korkmaz [17], the scientific process required more than organising the observable information and if the science is taught with these processes, the students acquire these skills and use in daily life, and they have more positive attitudes towards the science and their creativity skills develop. The scientific process skills is an approach focusing on the arrangement of skills which are the reflection of scientific behaviour, appropriate for different science disciplines and transferrable [18]. Likewise, Ewers [11] defines the scientific process skills as observation, classification, deduction, estimation, measuring and communication; however, he states that these skills provide a ground to scientific information, on the other hand, the scientific process skills are not included in science courses formally and many science curriculum focus on the content by ignoring how the information is developed.

According to Ferreira [2004], the researchers have defined three main aspects as the requirement and complementary component of the scientific education for the development of the scientific literacy, being a good tool for understanding the scientific information by catching up the changing speed of the information in relation with the mission of the scientific process skills in the science education [quoted by 20]. Therefore, it is so important for the science education to gain these skills. Likewise, Ongowo and Indoshi [25] mention that the aim of every science teacher is to promote the development of the scientific process skills and the use of these skills provide the students to search the important matters in the world and their close environment. One of the basic aims of the science education is to develop the scientific thinking and research skills. The scientific process skills are generally considered as an approach to be applied in a laboratory, so it is a laboratory approach [7]. In addition to the central role of the scientific process skills for the "meaningful learning", it is also the complementary for a scientific education [20]. The scientific process skills can also be described as the "learning to learn" determining how the learning is formed by using the critical thinking and creative information; learning with observation; organising the concepts, truths; assessing the results with reference to certain causes and commenting on the results; deduction by estimating the thing to be able to be changed [Martin et al., 2001; quoted by 27]. The creative thinking has a complementary role for the scientific process for the works in relation with the science and technology [1]. 
Therefore, the scientific creativity (creativity in science) education is considered to be one of the most crucial targets of the science curriculum and the content, structure and teacher approach of the course should be cared a lot. The creativity is an important aspect of human development. The technological developments and the globalisation trends require the productive and innovative people for all parts of the life. The education organisations have an important place for the development of the creativity skills and capabilities of the students and on that point the science education has the largest share for the improvement of the creative thinking quality [8].

\section{References}

1. Akçam, M. İlköğretim fen bilgisi derslerinde yaratıcı etkinliklerin öğrencilerin tutum ve başarılarına etkisi. Yayınlanmamış yüksek lisans tezi, Balıkesir Üniversitesi, Fen Bilimleri Enstitüsü, Balıkesir, (2007).

2. Aktamış, H., \& Ergin, Ö. Fen eğitimi ve yaratıcılık. Dokuz Eylül Üniversitesi Buca Eğitim Fakültesi Dergisi, 20, 77-83, (2006).

3. Ansal, H. bt haber, (2012). http://www.btnet.com.tr/54504-turk-egitim-sistemiyaraticiligin-onundeki-en-buyuk engel.html adresinden 10 Aralık 2013 tarihinde edinilmiştir.

4. Balc1, A. Sosyal bilimlerde araştırma yöntem, teknik ve ilkeler. Ankara: Pegem A Yayınc1lık. 4. Bask1, (2004).

5. Büyüköztürk, Ş. Deneysel desenler öntest-sontest kontrol grubu desen ve veri analizi. Ankara: Pegem A Yayıncılık. 1.Bask1, (2001).

6. Ceylan, E. Effect of instruction using conceptual change strategies on students' conceptions of chemical reactions and energy. Unpublished master thesis, Middle East Technical University, (2004).

7. Çepni, S., Ayas, A., Johnson, D., \& Turgut, M. Fizik öğretimi. Ankara: YÖK/Dünya Bankasi, (1997).

8. Daud, A. M., Omar, J., Turiman, P., \& Osman, K.. Creativity in science education. Procedia - Social and Behavioral Sciences, 59, 467-474, (2012).

9. Demir, S. Bilimsel tartışma ve araştırmaya dayalı tasarlanan laboratuvar programının, fen bilgisi öğretmen adaylarının bilimsel yaratıcılıklarına etkisi. Yayınlanmamış Doktora Tezi, Marmara Üniversitesi, İstanbul, (2014).

10. El Bassiti, L., \& Ajhoun, R. (2013). Toward an innovation management framework: A life-cycle model with an idea management focus. International Journal of Innovation, Management and Technology, 4(6), 551-559, (2013).

11. Ewers, T. G. Teacher-directed versus learning cycles methods: Effects on science process skills mastery and teacher efficacy among elementary education students. Unpublished $\mathrm{Ph}$. D. dissertation, University of Idaho, (2001).

12. Farooq, U. Supporting creativity: Investigating the role of awareness in distributed collaboration. The Pennsylvania State University, (2008).

13. Ferrari, A., Cachia, R., \& Punie, Y. Innovation and creativity in education and training in the eu member states: fostering creative learning and supporting innovative teaching. Luxembourg: Office for Official Publications of the European Communities, (2009).

14. Hu, W., \& Adey, P. A scientific creativity test for secondary school students. International Journal of Science Education, 24(4), 389-403, (2002).

15. Lin, C., Hu, W., Adey, P., \& Shen, J. The influence of case on scientific creativity. Research in Science Education, 33, 143-162, (2003). 
16. Kadayıfçı, H. Yaratıcı düşünmeye dayalı öğretim modelinin öğrencilerin maddelerin ayrılması ile ilgili kavramları anlamasına. Yayınlanmamış doktora tezi, Gazi Üniversitesi, Eğitim Bilimleri Enstitüsü, Ankara, (2008).

17. Kaptan, F., \& Korkmaz, H. Illköğretimde etkili ögretme ve ögrenme öğretmen el kitabı ilkögretimde fen bilgisi ögrretimi modül, (1999). 7. 09. 08. 2013 tarihinde http://sakarya63.sa.funpic.de/ilkogretimde_fenbilgisi_01.pdf adresinden alınd1

18. Karamustafaoğlu, O., \& Yaman, S.. Fen eğitiminde özel ögretim yöntemleri I-II. Ankara: Anı Yayınc1lık, (2006).

19. Kocabas, S. Elements of scientific creativity. AAAI Technical Report SS-93-01, (1993).

20. Kurtuluş, N. Yaratıcı düşünmeye dayalı öğretim uygulamalarının bilimsel yaratıcılık bilimsel süreç becerileri ve akademik başarıya etkisi. Yayınlanmamış yüksek lisans tezi, Karadeniz Teknik Üniversitesi, Eğitim Bilimleri Enstitüsü, Trabzon, (2012).

21. Liang, J.. Exploring scientific creativity of eleventh grade students in Taiwan. Unpublished doctoral dissertation, The University of Texas at Austin, Texas, (2002).

22. Meador, K. S. Thinking creatively about science suggestions for primary teachers. Gifted Child Today, 26(25), 25-29, (2003).

23. Miles, E. In-service elementary teachers' familiarity, interest, conceptual knowledge, and performance on science process skills. Unpublished master thesis, B.S. Southern Illinois University Carbondale, (2008).

24. Moghaddam, F. M., Walker, B. R., \& Harre, R. Cultural distance, levels of abstraction and the advantages of mixed methods. A. Tashakkori, \& C. Teddlie (Eds.) içinde, Handbook of mixed methods in social \& behavioral research (s. 111-134). California: Sage Publication, (2003).

25. Ongowo, R. O., \& Indoshi, F. C. Science process skills in the Kenya certificate of secondary education biology practical examinations. Creative Education, 4(11), 713717, (2013).

26. Park, J. Scientific creativity in science education. Journal of Baltic Science Education, 10(3), 144-145, (2011).

27. Rauf, R. A., Rasul, M. S., Mansor, A. N., Othman, Z., \& Lyndon, N. Inculcation of science process skills in a science classroom. Asian Social Science, 9(8), 47-57, (2013).

28. Şahin, F., \& Benzer, E. The effect of the project practices improved with four question strategy to science process skills. Necatibey Eğitim Fakültesi Elektronik Fen ve Matematik Ĕgitimi Dergisi (EFMED), 6(1), 306-337, (2012).

29. Şakir, T. The effect of multiple intelligences based instruction on students' achievement in basic compounds of living organisms concepts and attitude toward biology. Unpublished doctoral dissertation, Middle East Technical University, (2013).

30. Ünal Çoban, G. The effects of inquiry supported by argument maps on science process skills and epistemological views of prospective science teachers. Journal of Baltic Science Education, 12(3), 271-288, (2013).

31. Villalba, E. On creativity; towards an understanding of creativity and its measurements. İtaly Luxembourg: Office for Official Publications of the European Communities, (2008).

32. Wyke, R. M. Teaching creativity and innovation in higher education. Unpublished doctoral dissertation, University of Pennsylvania, (2013).

33. Zhang, J., Liu, G., \& Lin, C. An action-oriented approach to gifted education: Evidence from the field of scientific creativity. High Ability Studies, 23(1), 123-125, (2012). 